\title{
BETWEEN LITURGY AND THEATRE. THE JESUIT LENTEN MEDITATIONS FROM THE BAROQUE SILESIA
}

Significant changes in the artistic form of religious practices in Modern Europe were introduced by members of the Society of Jesus. Their activities in the field of art resulted directly from the constitutional priority of pastoral ministry (auxilium animarum), ${ }^{1}$ which in the face of contemporary challenges called for new forms of implementation. In a typical manner for the Jesuits, these forms often combined methods of pastoral influence borrowed from the tradition and contemporary strategies of religious persuasion tested through practice, the latter being adequate for a clearly defined group of recipients. An important field for these experiments was of course music, naturally present in the majority of Christian forms of cult and ritual. The music's immanent values resulted from the Church's century-old tradition, and its employment was warranted by current pastoral needs. The accurate identification of these needs led to the dynamic development of music for the theatre and the oratorio.

The Jesuits devoted their greatest attention to the school drama, which was of special utility as an educational element due to the schools run by the Society. This utility resulted from tying together the actors' play, declamation, emblematic art, pantomime, song, dance, and stage design into an original whole. Mastering the enumerated abilities qualified the students of Jesuit colleges for active participation in public and social life. ${ }^{2}$ However, acquiring this mastery also served the integral formation of its recipients, which comprised both the viewers of the spectacle, and the actors presenting the content. This character formation was in turn enabled by the elements of psychological introspection: visualization of the individual's emotional state, and its resolution controlled by means of a fictional

1 STECZEK, Bogusław, KOŁACZ, Jakub (eds.). Konstytucje Towarzystwa Jezusowego wraz z przypisami Kongregacji Generalnej XXIV oraz Normy uzupetniajace zatwierdzone przez te sama Kongregację. Kraków: Wydawnictwo WAM, Warszawa: Polskie Prowincje Towarzystwa Jezusowego, 2006 (Formuły, 1), 29. 1952, Vol. 4, No. 4. p. 283-292. 
plot. In this sphere, the Jesuit school drama was the artistic equivalent of the Ignatian Spiritual Exercices, which employed the method applicatio sensuum, i.e. the meditative use of experiences acquired with the imagination's senses. The sensations were used for imagining the place of the contemplated content and its emotional feeling, complementary to intellectual cognition. Not incidentally, these two phenomena, which relate to the world of imagination and the events presented on the theatrical stage, were referred to as repraesentatio.

Even closer ties with the Ignatian Exercices were maintained in the so-called Lenten meditations, i.e. spoken word and musical spectacles of Passion content, presented in the successive Sundays of Lent by the Latin sodalities of Jesuit gymnasium students. ${ }^{3}$ For reasons of these genres' constitutive poetics, they may be considered as being related to the Jesuit school drama. However, their dramaturgy stemmed directly from the community-oriented religious training given in the sodalities, hence their form, exhibiting analogies with the schemata of the Ignatian method. The general architecture of the meditationes quadragesimales is arranged into a three-stage cycle: the theme under consideration (materia), selected strands of content (punctum), and indication of the expected meditation effect (fructus). Thus, engaged in the successive stages of the deliberations were the recipient's memorative, intellectual, and volitional faculties, leading him through the proper stages of the via illuminativa. ${ }^{4}$ A skillfully selected concept in turn served the cathartic experience of purgatio. ${ }^{5}$ The content of this concept was underscored, intensified, and illustrated by appropriately selected music, which according to Jesuit theoreticians - was perfectly suited ad affectuum movendum and ad virtutis aemulationem. ${ }^{6}$

3 SAMMER, Marianne. Die Fastenmeditation. Gattungstheoretische Grundlegung und kulturgeschichtlicher Kontext. München: tuduv 1996 (Kulturgeschichtliche Forschungen 22. Ed. MOSER, Dietz-Rüdiger); ERLACH, Thomas. Unterhaltung und Belehrung im Jesuitentheater um 1700: Untersuchungen zu Musik, Text und Kontext ausgewählter Stücke. Essen: Die Blaue Eule, 2006, p. 65.

4 About the connection between the Ignatian tradition with St. Bonaventure's original De triplici via model, see MAGNIEZ, Anne-Claire. Des Exercices spirituels théâtralisés et musicaux. L'exemple du Theatrum Solitudinis Asceticae de Franciscus Lang SJ (1717). In Aurora Musas nutrit - Die Jesuiten und die Kultur Mitteleuropas im 16.-18. Jahrhundert. Acta conventus, Bratislavae 26.-29. Septembris 2007. Eds. KAČIC, Ladislav, ZAVARSKÝ, Svorad. Bratislava: Slavistický ústav Jána Stanislava SAV, Teologická fakulta Trnavskej univerzity, 2008, p. 135-144, here p. 136-137.

5 MASEN, Jakob. Palaestra eloquentiae ligatae dramatica ... Köln: Johannes Busaeus, 1657, lib. I, cap. II $\S 2$, p. 5.

6 LANG, Franz. Theatrum solitudinis asceticae, sive doctrinae morales per considerationes melodicas ad normam S. Exercitiorum S. P. Ignatii compositae... München: Mathias Riedl, 1717, p. 4v: "Ut mitius sentias, ipsam naturam Musices bonus consule. Habet illa nescio quid amabilis violentiae, quae dominari solet audientium animos, eosque modulorum suavitate fascinatos in sui amorem trahere. Isto quasi canali robustae veritates \& vitae Christianae principia in mentes hominum leniter influunt \& amoenitate cantus instillatae, fortius haerent in affectu \& memoria; unde per moram illustratus intellectus, ipsam quoque voluntatem, 
Because of these immanent qualities, the music was able to function as a perfect medium to the transmitted content, and simultaneously evoke the affect it carried, intensifying this content's persuasive effect on the field of voluntas. This was also true of instrumental music's non-verbal message, which accompanied pantomimes and sequences of emblems. The meaning of this type of music was no less effective: paradoxically, it intensified the viewer's concentration on the emblematic message, devoid of the verbal stratum: by masking the amount of the reaching stimuli, it subliminally affected the recipient's cognitive faculties. ${ }^{7}$ Practical affirmation of the theoretically formulated, written Lenten meditation poetics is furnished by a printed collection of this type of spectacle, which was staged by the Munich sodality of the Annunciation of the Blessed Virgin Mary. ${ }^{8}$ The music coupled with the text truly is ciendis affectibus accomodata, the particular elements of the spectacle tied together with the principle of decorum, and its content effectively influential on the world of imagination, intellect, and volitional faculties of the recipient. The meditations assume a three-stage form, comprising the initial expositio read by the prefect, the communally weighed considerationes, and the crowning affectus modulis musicis decantatus.

Accompanying the extant, printed-source Lenten meditations of Bavarian provenance, are musically notated compositions by local composers. ${ }^{9}$ They form sequences of recitatives, arias, duets, ensembles, choirs, and ritornellos, each sequence preceded by a prelude, sinfonia, overture, or sonata. This introductory part of the meditations fills a function analogous to the Ignatian exercise compositio loci. The particular sections of meditationes are destined for solo voices and varied instrumentation, which produces a form in proximity to oratorio genres. Passion meditations of musical richness spread as a practice in German-speaking countries, ${ }^{10}$ also making its way to the Czech lands and Silesia, where they were cultivated by Latin student sodalities. Their musical component was usually realized with the participation of the local boarding school pupils, with responsibil-

modulaminis titillatione devinctam, in agnitae veritatis amorem \& virtutis aemulationem abripiat; qui unus nostri laboris scopus \& finis est."

LANG, Franz. Theatrum affectuum humanorum, sive considerationes morales ad scenam accomodatae... München: Mathias Riedl, 1717, p. 5v: "Pascendis oculis et informando intellectui excogitata illa fuere, ut dum auris occupabatur canentium modulis aut sermonibus actorum, simul per oculum ingressa veritas haereret firmius in animis, propositarum imaginum figuris et lemmatum stricturis illustrata."

LANG, Franz. Theatrum doloris et amoris sive considerationes mysteriarum Christi patientis, et Mariae Matris Dolorosae sub cruce condolentis Filio piis affectibus conceptae, et in oratorio Almae Sodalitatis Maioris B. V. Mariae ab Angelo salutatae Monachii per verni ieiunii sabbathinos dies sub vesperum DD. Sodalibus pie meditantibus ad lampades expositae. München: Mathias Riedl, 1717, Preface.

Among others, Joseph Anton Bernabei, Franz Mathias Delaman, Judas Thaddäeus Holl, and Rupert Ignaz Mayr.

10 VALENTIN, Jean Marie. Les jésuites et le théâtre (1554-1680). Contribution à l'histoire culturelle du monde catholique dans le Saint-Empire romain germanique. Ed. BEHAR, Pierre, Paris: Desjonquères, 2001, p. 98. 
ity assumed by the institution's prefect. ${ }^{11}$ Altogether, a rather limited number of performers were engaged in the meditations' presentation. ${ }^{12}$

The Lenten meditations taken in Silesian colleges were similar in shape, particularly in Breslau, whence comes the most ample documentation. ${ }^{13}$ Although this documentation completely lacks music, we can partly reconstruct it on the basis of libretto texts furnished with stage directions, per analogiam with the material of Bavarian provenance. Passion meditations in Breslau were organized by the sodality of the Annunciation of the Blessed Virgin Mary, active in the city from 1639 and uniting the elite youth of the Jesuit gymnasium. From the very inception of its existence, the brotherhood met on the successive Sundays of Lent for meditative services at St. Matthias', and later at St. Agnes' Church. ${ }^{14}$ Regular presentations began in 1647 , by which time they were already tied in with a musical performance, inter modulos musicos. ${ }^{15}$ Presentations described in the sodality's chronicle ${ }^{16}$ were on the Passion theme, customarily shown in OldTestament alegoresis, a fact indicated by a mention about the title of a publication distributed on the occasion. ${ }^{17}$

The Litterae annuae prepared in the Czech province of the Society of Jesus indicate unequivocally that the meditationes tradition grew around the practice of singing the Miserere Psalm, regularly performed in the afternoons of Lenten work days. Although the psalm extended beyond the official Liturgy of the Hours canon, it could be counted among the liturgical repertoire due to its content and

11 Brno, Moravský zemský archiv (hereafter BMZA) G 10, č. 267, p. 247: "Per Quadragesimam solent meditationes de Passione fieri. Expedit autem, ut ea ipsis diebus Dominicis, vel ordinario Conventus tempore, vel post vesperas hora tertia, habeantur: nam sic sodales non impediuntur in studiis, et cum maiore fervore ac diligentia Meditationes illas tunc faciunt [...] Praefectus musicae tempestive moneri debet, ut de idoneis symphoniis et cantibus provideat." Quotation after MAŇAS, Vladimír. Hudebni aktivity náboženských korporací na Moravě v raném novověku. Disertační práce, Ústav hudební vědy Filozofické fakulty Masarykovy univerzity. Brno 2008, p. 142.

The 1663 meditations in the Olomouc sodality of the Assumption of the Blessed Virgin Mary were accompanied by four lutists. ORLITA, Zdeněk. Postní a velikonoční období v praxi olomouckých jezuitských sodalit v druhé polovině 17. století. Časopis Matice moravské, 2006, vol. 125, no. 1, p. 53-76, here: p. 56.

13 Cf. JEŻ, Tomasz. Kultura muzyczna jezuitów na Ślasku i ziemi kłodzkiej (1581-1776), Warszawa, Wydawnictwo Naukowe Sub Lupa, 2013, p. 596-600.

14 Breslau [1639]: Praha, Národní knihovna, Oddělení rukopisů a starých tisků (hereafter: CZNK ORST), XXIII D 168, p. 126.

15 Breslau [1647]: Roma, Archivum Romanum Societatis Iesu (hereafter: ARSI), Boh. 96, k. 341; [1648]: ARSI, Boh. 96, p. 423.

16 Breslau [1649]: Wrocław, Archiwum Archidiecezji Wrocławskiej (hereafter: WAAW), II b 129 , f. $6 \mathrm{v}$.

17 Breslau [1659]: WAAW II b 129, k. 29v: "Invenies hoc anno Suo loco insignes Benefactores, ex quorum munificentia praeter alias expensas Sodalitatis Meditationem de amara Passione Domini imprimi fecit, quam alijs documentis ad pietatem servientibus auxit, libellumque, [...] cui titulus Adamas Humani cordis humilissimo Christi patientis sanguine edomandus, inter sodales cum fructu sparsit." 
function. From the pastoral viewpoint, this practice was qualified as poenitentiae admonitio ${ }^{18}$ since the musical performance of Psalm 51 was normally accompanied by a catechesis on a Passion theme, addressed to the sodality gathered for the occasion. ${ }^{19}$ This custom, noted in the chronicles of Prague's college, spread momentously through the province, and were already the required norm in the mid-seventeenth century. ${ }^{20}$ In 1634 , the discussed psalm was sung by Jesuits from Glatz, ${ }^{21}$ who used bell ringing to call the faithful to participation; three years later the singing of the psalm was accompanied by a short exhortatio. ${ }^{22}$ In the following year, singing of the Miserere began in Schweidnitz, ${ }^{23}$ and was immediately fruitful in long lineups to the confessional. ${ }^{24}$

In 1639, the practice was begun in the St. Matthias' Church made available to the Breslau, where Jesuits, who gave Passion sermons, moving the crowds gathered in the auditorium. ${ }^{25}$ The sermons normally drew on the themes of penance, usually derived from Biblical parables. ${ }^{26}$ Extant descriptions of this practice often point out the liturgically suitable character of the psalm's musical arrangement, whose $\mathrm{sad}^{27}$ and appropriately performed ${ }^{28}$ melody reverberated sympathetically with the subsequently expounded content. ${ }^{29}$ The musical performance of the Miserere was thus supposed to prepare the listeners to receive the essence of the catechesis. Instrumental use of musical performance during the catechetic process resulted in the Jesuit clergy's sermons bearing even richer fruit, and induced the listeners to increased piety. ${ }^{30}$ Perception of this rule was the very source of initiating the new expression of Lenten piety, i.e. the meditationes quadragesimales and the series-crowning theatrical spectacles given by the same sodality on Palm Sunday.

Models of the Ignatian method are found in the synopses of Silesian Passion meditations extant in Breslau. Their architecture is based upon a sequence of several puncta, which consist of a Biblical figura and a meditational applicatio,

18 SCHMIDL, Johann. Historiae Societatis Jesu provinciae Bohemiae... Praha, 1754, vol. III, p. 59.

19 Ibid, 1759, vol. IV/1, p. 311.

20 ARSI, Boh. 192, p. 109r.

21 ARSI, Boh. 95, p. 66.

22 CZ-Pn ORST, XXIII D 168, p. 121 [1637].

23 ARSI, Boh. 95, p. 520 [1638].

24 WAAW, V 46, f. 21 [1638].

25 WAAW, V 39, f. 15v [1639]; SCHMIDL, op. cit., Vol. III, 561.

26 E.g. about Job's suffering: ARSI, Boh. 96, p. 342 [1647], or the prodigal son: ARSI, Boh. 96, p. 48 [1649].

27 ARSI Boh. 96, p. 48 [1649].

28 SCHMIDL, op. cit., Vol. III, 59.

29 Breslau [1665]: WAAW, V 39, p. 46r.

30 Breslau [1661]: ARSI, Boh. 98, p. 194. 
crowned by a colloquium Animae amantis ad Christum crucifixum. ${ }^{31}$ The entire meditation opened with a more or less musical praeludium, sometimes furnished with a subtitle illustrating its function: loci constitutio. ${ }^{32}$ From the beginning of the eighteenth century, a permanent element of the meditations were the musical intermedi crowning the successive puncta. The intermedia accompanied staged pantomimes, which presented Biblical paradoxa, and were referred to with the term concentus musicus ${ }^{33}$ or affectus musicus. ${ }^{34}$ Thus, the intermedi were not "interruptions" in the meditations devoid of content, but elements key in their development, serving the interiorization of the ideas under consideration and allowing time for participants to assume the expected volitional act. ${ }^{35}$ Hence, aesthetically speaking, the musical experience served the rhetorical articulation of the conclusio, creating in parallel to the intellectual pathway, an aesthetic-emotive experiential one, the latter being specially valued in the Jesuit writings of the time.

Beginning with the synopses of Breslau meditationes of the 1740s, texts of arias figure at the close of the meditations. ${ }^{36}$ These arias were set forth in a special musical appendix ${ }^{37}$ added to the meditations or written out in extenso within the libretto, ${ }^{38}$ affirming the "words-and-music" character of the spectacles. Interestingly, and this needs to be emphasized, the described tradition continued without break also after the announcement the Society of Jesus' cassation in Silesia, and formed a significant element of religious life schooling in the Catholic Breslau until the very end of the eighteenth century. The synopses originating in the 1780s also note the presence of other musical elements in the content of the meditations, such as recitatives sung by soloists within the successive puncta, the performers being indicated by reference to their voices. ${ }^{39}$ Reconstructing how the meditations unfolded may be enriched with the use of stage directions, present in some synopses and indicating the performance of specific liturgical compositions in the meditations' course (although the authorship of these arrangements is unknown).

In the surviving libretti of meditations from the Annunciation of the Blessed Virgin Mary sodality in Glatz prepared by its prefect Georg Auschitzer (who in

31 Contemplatio mortis Jesu Christi ex similitudine mortis Filii... Breslau 1669. Wrocław, Biblioteka Uniwersytecka, Gabinet Śląsko-Łużycki (hereafter: PL-WRu GŚŁ, Yu 85/2).

32 Christo pro mundi salute mortuo... Breslau 1710 (PL-WRu GŚŁ, Yu 85/36).

33 Verbi divini pro homine in carne passi paradoxa... Breslau 1718 (PL-WRu GŚŁ, Yu 85/44).

34 Jesus Christus bonitate voluntatis suae Salvator omnium... Breslau 1737 (PL-WRu GŚŁ, Yu 85/56).

35 SAMMER, op. cit., 16, 35.

36 Ecce Homo, Deus Homo... Sanctoris Vitae Speculum Illustrimae Rhetorices Facultati Exercitationis hebdomadariae Argumentum... Breslau 1741 (PL-WRu GŚŁ, Yu 50/344).

37 E.g. Amara Christi Passio poenitenti anime dulcis consolatio... Breslau 1742 (PL-WRu GŚŁ, Yu 85/87).

38 E.g. Regia Crucis \& Salutis via patientis Christi... Breslau 1743 (PL-WRu GŚŁ, Yu 85/88).

39 E.g. Mysteria patientis Domini nostri Jesu Christi... Breslau 1782 (PL-WRu GŚŁ, Yu $85 / 122)$. 
1685 also filled the function of choir regent in the local boarding school $)^{40}$ we also discover affectus musicus, crowning the successive puncta with sung arias. ${ }^{41}$ Apparent in another synopsis of a Glatz meditation ${ }^{42}$ are the successive verses of Good Friday's Adoramus te Christe, presented in the form of epigrammatic inscriptions as well as their original, i.e. vocal shape. The para-liturgical character of Passion meditations is also emphasized by the inclusion of hymnic forms in their structural architecture: the above-mentioned occasion included the singing of the hymn Vexilla regis, while another meditation was crowned by the hymn Te Deum. ${ }^{43}$ The musical performance contexts of meditationes quadragesimales are revealed by Litterae annuae, originating also from other centres of the Jesuit Silesia, including Neisse, ${ }^{44}$ Schweidnitz, ${ }^{45}$ Oppeln, ${ }^{46}$ and Liegnitz, the latter being a location where the Sacred Heart Sodality staged this type of spectacle cum affectuosis modulis musicis partitas devote.$^{47}$ Also testifying to the para-liturgical character of the Lenten meditations are the statutes of Moravian sodalities, according to which the performances were preceded by the communal singing of the hymn Veni Creator Spiritus along with an antiphone, verse, and short prayer. ${ }^{48}$

In the presently surviving musical repertoire of Jesuit provenance there figure several compositions which may well have been performed on the occasion of

40 Kraków, Archiwum Prowincji Południowej Towarzystwa Jezusowego, 2760, p. 75.

41 WAAW, V 52: "Meditationes 5 proposita Glacij Anno 1684, in Congregatione Latina Maiore: Meditatio I. De mysterio $1^{\circ}$. Doloroso. Punctum 1. Agonia Christi. Hortus Olivarum, in hoc Jesus flectenti similis, et curvans, ab Angelo sustentatur una manu Christum fulciente, altera manu Calicem erectum monstrante, et consolante. Cantus: Peccator crudelissime.

Punctum 2. Captivitas Christi, Jesus in medio satellitum armatorum fustibus, lanceis, gladijs, lucernae, faces ardent, funibus, catenis, quasi truncus ruens, ligatus representatus. Cantus: Jesu, Caeli delicium.

Punctum 3. Iniuriae Christo capto illatae: In domo Caiphae ad columnam erectam, lonqam, manibus post terga revictis alligatus, velatus faciem, conspicitur, ridetur, colaphizatur, capillis trahitur, bacillis tunditur. Cantus: ,Jesu Davide Pulchrior '."

Adoratio Christi Per Sanctam Crucem Suam Mundum Redimentis Iuxta Versiculum Officij Parvi de Sancta Cruce, Glatz 1685 (WAAW, V 52).

43 Octo beatitudines ab ipso Domino nostro Jesu Christo, qua verbis praedicatae, qua copioso aerumnosissimae vitae ac mortis exemplo confirmatae... Breslau 1788. Wrocław, Biblioteka Uniwersytecka, Oddział Starych Druków (hereafter: PL-WRu OSD, 365409).

44 Neisse [1675]: ARSI, Boh. 102, p. 555; [1705]: ARSI, Boh. 118, p. 139.

45 Jesus, Maria, Bernhardus, seu pia meditatio de Christo patiente, Maria compatiente, Bernardo Passionem hanc ita proponente... Schweidnitz 1676.

46 HOFFMANN, Hermann. Die Jesuiten in Oppeln. Die Tätigkeit der Jesuiten in d. Fürstentümern Oppeln u. Ratibor, den Standesherrschaften Beuthen und Pleß, in Oberglogau und Ziemientzitz, in Oppeln Tarnowitz und Piekar, in den Volksmissionen und den neuen Niederlassungen (Zur schlesischen Kirchengeschichte, 8). Breslau: Frankes Verlag, Otto Borgemeyer 1934, p. 166.

47 Liegnitz [1712]: ARSI, Boh. 125, p. 90; [1730]: ARSI, Boh. 147, p. 149.

48 Leges, et Statuta Sodalitatis Beatissimae Virginis Mariae Assumptae, inter externos Studiosos in Academia Sociatatis Iesu Olomucij fundatae. Olomouc: Georg Handl 1605, pars prima, p. 8. 
the meditationes quadragesimales. An example of these is Christoph Todtfeller's Geistliches Hirten-Lied von dem verlohrnen Schäflein ${ }^{49}$ added to his Jesuit's Lenten sermons and performed as part of the meditations. The musical compositio loci of this 16-verse Good Shepherd song is created with the thick texture of five string instruments and basso continuo. In phrases repeated alternatim, it communicates exactly what is being sung by the lyric subject of the verse. Perhaps this correspondence was meant to suggest to the listener the experiential identity of the five senses and the intellect while cognizing Christ the bridegroom.

An analogous concept seems to be revealed in the solo concerto $O$ Domine Jesu, composed by Karl Rabovius, ${ }^{50}$ a Jesuit active in Glatz, among other places. The work's verbal text ${ }^{51}$ makes direct reference to the services of the Five Sacred Wounds of Christ cultivated by Jesuit sodalities, the theme and content of such services perhaps associating them with presentations of the meditationes. The much later composed Tres Ariae cum Epilogo de passione Domini by Anton Svoboda $^{52}$ may have been of analogous use, as it completes the meditation texts signalized in the synopses and corresponds to the Affecti melodici added to their programs. ${ }^{53}$ The composers engaged in setting the music to Silesian meditationes were most probably those of the sodalities' custodians, who simultaneously filled the responsibilities of boarding school prefects. We must first mention here those patres, who are known to have occupied themselves with composition: An-

49 Das Verlohrne Schaaf, Das ist: Fasten-Exhorationes, In welchen eine Sündhaffte Seel, so gleich einem jrrendem Schäfflein, durch allerhand Müssbrauch der Creaturen, von deren Schöpffer abgewichen; [...] Eine Lob-Predig von dem Heiligen Patriarchen Ignatio, Stiefftern der Societät Jesu, In welcher Hochgedachter Heiliger Vatter einem Frommen Wolff verglichen wird, Geprediget In dem Oratorio dess Kayserlichen Collegii Societate Jesu, in der Stadt Breslaw von dem Ehrwürdigen P. Christophoro Todtfeller, der Soc: Jesu Priestern, und H. Schrifft Doctore... Praha 1677. Olomouc, Vědecká knihovna v Olomouci, 601.783.

50 KAPSA, Václav. Jesuiten komponieren. Bemerkungen zu den erhaltenen Kompositionen der böhmischen Jesuiten. In. Aurora Musas nutrit - Die Jesuiten und die Kultur Mitteleuropas im 16.-18. Jahrhundert. Acta conventus, Bratislavae 26.-29. Septembris 2007. Eds. KAČIC, Ladislav, ZAVARSKÝ, Svorad. Bratislava: Slavistický ústav Jána Stanislava SAV, Teologická fakulta Trnavskej univerzity, 2008, p. 193-208, here p. 196-198.

51 Warszawa, Biblioteka Uniwersytecka (hereafter: PL-Wu), RM 6289: "O Domine Jesu Christe, Deus cordis mei, vita mea, anima mea, qui natus, passus, mortuus es pro nobis, obsecro te per illa quinque vulnera quae tibi in cruce nostri amor inflixit, obsecro, famulis tuis subveni, quos pretioso sanguine redemisti. Amen."

52 This Jesuit was a prefect to the music of boarding schools in Prague [1741/1742], Breslau [1742-1744], and Glatz [1744/1745]. TROLDA, Emilián. Jesuité a hudba. Cyril, 1940, vol. LXVI, nos. 5-6, p. 53-57, 1940, vol. LXVI, nos. 7-8, p. 73-78; 1941, vol. LXVII, nos. 1-2, p. 2-10, 1941, vol. LXVII, nos. 3-4, p. 42-46, 1941, vol. LXVII, nos. 5-6, p. 53-63, 1941, vol. LXVII, nos. 7-10, p. 106-108, here: p. 62.

53 Praha, Národní Muzeum - Muzeum České Hudby, Hudební Archiv (hereafter PNM-MČH), XXXVIII A 315: Tres Ariae Cum Epilogo De passione Domini. I. [Stupesce homo Christus jacet] à Canto Solo, Violinis 2, Viola, Huboa Sola, Clarino cum Sordinis ex Dis et fundamento. II. [Non est homo] à Canto solo, Violinis 2, Viola et fundamento. III. [O Amor] ab Alto Solo, Violinis 2, Viola et fundamento. Epilogus [O immensa regis aeterni] à Canto, Alto, Tenore, Basso, Violinis 2, Viola et Organo. Auth: R: P: [Antoni] Swoboda e Soc: Jesu. 
dreas Lincke, author of suavissimo musici concentu, performed ad satisfactionem aurium, ${ }^{54}$ Franz Christen, author of 11 compositions known by title, ${ }^{55}$ and Joseph Wiesner, whose works include an aria that could have successfully been performed in the program of the meditationes as an affectus musicus. ${ }^{56}$

Johannes Thamm ${ }^{57}$ composed the Opella de Passione Domini ${ }^{58}$ which comprises 12 pairs of recitatives and arias destined for performance (in twos) on each of the six Sundays of Lent. While dividing the entire composition into parts performed weekly significantly weakens the perception of the entire form, the device aims to musically uniformize the services celebrated within this time, creating a type of Lenten "series". By means of dividing the composition's storyline into several episodes, this "series" arouses in its recipients a natural interest in the continuation, motivating the attendees to participate in the community meetings supplied with music. The musical arrangement of the subsequent sections of the Opella de Passione Domini uses the outline of a developed recitative and da capo aria, both repeated weekly; however, each following Sunday brings enrichment to the vocal texture and variety to the instrumental accompaniment through the use of obbligato instruments. The general outline of the architecture is shown in the following table:

54 WAAW, V 46, p. 27.

55 In a surviving inventory of musical paraphenalia from the Jesuit college in Uherské Hradiště (BMZA 5838) from 1730, the following compositions of his authorship are listed: Litaniae duplices brevissimae $1^{a e}$ sub tit. Salus infirmorum, $2^{a e}$ sub tit. Consolatrix afflict; Salve Reg[ina]: Affabile; Alma Red[emptoris] Mater; 4 settings of the Ave Regina, 2 settings of the Regina Coeli duplex and Hymnus de confess[ore]. See SEHNAL, Jiř́i. Hudba v jesuitském semináři v Uherském Hradišti v roce 1730. Hudebni věda, 1967, vol. 4, p. 139-147, here: p. $142,147$.

56 Aria solemnis A: Canto Solo, Violino Primo, Violino secundo, Alto Viola, Cornibus 2bus ex D: et organo. Del. Sig: D[omin]o Josepho Wiesner. Coeli cives occurrite. $\mathrm{Huc}$ ad festum. Nowadays in PNM-MČH, XL B 5.

57 Until the cassation, he was choir prefect for a period of 16 years in Glogau [1744-1748], Olomouc [1753-1754], Neisse [1754/1755], and Breslau [1764/1765], among other places. ARSI, Boh. 202, p. 191r.

58 PL-Wu RM 5032 [olim: Mf 1042]: Opella | De Passione Domini | e Reverendissimo, Perillustrissimo ac Amplisissimo | Domino, Domino | Franscisco Xaverio Meisner | Ducat: Canoniae \& Colleg: Ecclesiae | B. M. V. In Arena Wratislaviae | \& Collegiatae Eccles: S. Michaelijs Rosenbergae | Ordinis S. Augustini | Canonico: Regular: Lateranens: | Abbati, | ac Praelato et Infulato | Domino | Per Poloniam \& Sylesiam Visitatori generali... reverendissime oblata a P. Joanne Thamm | Presbytero Ecclest: p: d: Praesidie Congreg: | Latinae Majori | die 22 Oct. 1777. 


\begin{tabular}{|c|c|c|c|c|c|}
\hline performance time & form & tempo & voice(s) & textual incipit & $\begin{array}{l}\text { instruments } \\
\text { added to the } \\
\text { combination vl, } \\
\text { a-vla 1, org }\end{array}$ \\
\hline \multirow[t]{2}{*}{$\begin{array}{l}\text { Dominica Ima } \\
\text { post punctum Imum }\end{array}$} & $\begin{array}{l}\text { recitativo } \\
\text { - arioso }\end{array}$ & Adagio & $\mathrm{T}$ & $\begin{array}{l}\text { O adoptandis gratiam, } \\
\text { o pietatem }\end{array}$ & \\
\hline & aria & Affectuoso & $S$ & $\begin{array}{l}\text { O quanta pietas aeternae } \\
\text { voluntatis }\end{array}$ & ob $1-2$, cor $1-2$ \\
\hline \multirow[t]{2}{*}{ post punctum $2^{\text {dum }}$} & $\begin{array}{l}\text { recitativo } \\
\text { - arioso }\end{array}$ & $\begin{array}{l}\text { Adagio } \\
\text { molto }\end{array}$ & ST & $\begin{array}{l}\text { Heu, quam lugubris auribus } \\
\text { vox illabitur }\end{array}$ & \\
\hline & aria & Vivacissimo & $\mathrm{T}$ & $\begin{array}{l}\text { Valete gaudia, qua mundus } \\
\text { propinat }\end{array}$ & cor $1-2$ \\
\hline \multirow[t]{2}{*}{$\begin{array}{l}\text { Dominica IIda } \\
\text { post punctum Imum }\end{array}$} & $\begin{array}{l}\text { recitativo } \\
- \text { arioso }\end{array}$ & & SA & $\begin{array}{l}\text { O majestatem, o Dei nostri } \\
\text { sanctitatem }\end{array}$ & \\
\hline & aria & Andante & A & $\begin{array}{l}\text { Quam languit pietas dum Deus } \\
\text { ignoravit }\end{array}$ & cor 1-2 \\
\hline \multirow[t]{2}{*}{ post punctum $2^{\text {dum }}$} & recitativo & Grave & SATB & Assurge anima & \\
\hline & duetto & Largo & SA & $\begin{array}{l}\text { O regnum gratiae quod dudum } \\
\text { perdidi }\end{array}$ & vla 2 , cor $1-2$ \\
\hline \multirow[t]{2}{*}{$\begin{array}{l}\text { Dominica III } \\
\text { post punctum Imum }\end{array}$} & $\begin{array}{l}\text { recitativo } \\
\text { - arioso }\end{array}$ & Adagio & SB & Heu, quibus lamentis & \\
\hline & aria & Moderato & B & Cur tantis tandem & \\
\hline \multirow[t]{2}{*}{ post punctum $2^{\text {dum }}$} & recitativo & Largo & SATB & $\begin{array}{l}\text { Ah, videmus hominem percus- } \\
\text { sum a Deo }\end{array}$ & \\
\hline & $\begin{array}{l}\text { aria a } \\
\text { choro }\end{array}$ & $\begin{array}{l}\text { Adagio } \\
\text { molto }\end{array}$ & SATB & $\begin{array}{l}\text { Quis dabit oculis nunc fontem } \\
\text { lacrymarum }\end{array}$ & ob $1-2$, cor $1-2$ \\
\hline \multirow{2}{*}{$\begin{array}{l}\text { Dominica IVta } \\
\text { post punctum Imum }\end{array}$} & recitativo & Andantino & ST & Utinam per agni hujus merita & \\
\hline & aria & Andante & S & O crucis pretium & fl, cor $1-2$ \\
\hline \multirow[t]{2}{*}{ post punctum $2^{\text {dum }}$} & recitativo & & SB & Nunquid hac filii & \\
\hline & duetto & Furioso & SB & An Dei filius pro te languescit & ob $1-2$ \\
\hline \multirow[t]{2}{*}{$\begin{array}{l}\text { Dominica Vta } \\
\text { post punctum Imum }\end{array}$} & $\begin{array}{l}\text { recitativo } \\
\text { - arioso }\end{array}$ & & AS & Ora, o tenebrae & \\
\hline & aria & Spiritoso & A & $\begin{array}{l}\text { Ut fractis fulmen horrendum } \\
\text { intonat }\end{array}$ & \\
\hline \multirow[t]{2}{*}{ post punctum $2^{\text {dum }}$} & recitativo & $\begin{array}{l}\text { Molto } \\
\text { adagio }\end{array}$ & STB & $\begin{array}{l}\text { Ah contremisco me ipsam } \\
\text { horreo }\end{array}$ & \\
\hline & duetto & Maestoso & TS & Sint foris pugnae amoris & cor $1-2$ \\
\hline \multirow{2}{*}{$\begin{array}{l}\text { Dominica } \mathrm{VI}^{\text {ta }} \\
\text { post punctum Imum }\end{array}$} & recitativo & & SATB & O peccatum, heu malum & \\
\hline & aria & $\begin{array}{l}\text { Largo con } \\
\text { sordini }\end{array}$ & $S$ & Ah, odit Deus impium & \\
\hline \multirow[t]{2}{*}{ post punctum $2^{\text {dum }}$} & recitativo & & SATB & $\begin{array}{l}\text { Eja fons gratiae bonorum } \\
\text { honores }\end{array}$ & \\
\hline & $\begin{array}{l}\text { aria a } \\
\text { choro }\end{array}$ & $\begin{array}{l}\text { Andante } \\
\text { molto con } \\
\text { affetto }\end{array}$ & SATB & $O$, fons salutis res & ob $1-2$, cor $1-2$ \\
\hline
\end{tabular}

Tab. 1: The musical arrangement of the subsequent sections of the Opella de Passione Domini. 
There is nothing unusual in the existence of this type of cyclic form, considering the contemporaneous oratorio as background. However, our attention is drawn to what the musical notation reveals about the genre origins of this oratorio which constitute a not altogether distant echo of the Jesuit meditationes quadragesimales. The organizational outline of its musical form is also an important testimony to the Jesuit-specific regulation of communal time, traces of which are found in other types of cyclically developing worship services stemming from the conceptual tradition of the contemporaneous devotional literature. ${ }^{59}$ The rhythm of musical form, borrowed from the liturgical tradition, served to shape ordered varieties of religious life in the community, which accepted the meditated content by means of the performing arts. Combining these two domains of cultural activity in the Jesuit meditationes quadragesimales should well be considered as a specially successful proposition.

Translation by Maksymilian Kapelański

Tomasz Jeż (tomasz.jez@uw.edu.pl), Instytut Muzykologii, Uniwersytet Warszawski.

\section{BETWEEN LITURGY AND THEATRE. THE JESUIT LENTEN MEDITATIONS FROM THE BAROQUE SILESIA}

The pastoral practice of Jesuits in early modern Silesia involved a variety of cultural experiences. Its objective was to influence and transform the religious life of diverse social circles. In order to fulfill their purposes, they used different strategies both adopted from the tradition and newly invented ones. One of the fields of their experiments was music, which served both to enrich various forms of the liturgy and to strengthen the persuasiveness of various genres of Jesuit school drama.

Both trends interfered in the hybrid form of the Lenten meditations, organized by Marian Sodalities and served to those communities. The meditationes quadragesimales paradoxically combined elements of the liturgical worship with theatre performance. Its keystone was the concepts of compositio loci and applicatio sensuum borrowed from Ignatian Spiritual Exercises. Both methods served for the sensual representation of the spiritual themes and their meditation, presented for the community but carried on by its individuals. Its social impact was extremely large, because of its synesthethic poetics, which combined language, visual, movement, design and music elements. The perception of such multimedia repraesentatio should develop in the audience the ability of describing and controlling their own emotions. Of equal importance was the rhetorical form of presentation itself, which encouraged the addressees to identify with the presented contents.

Music performed in this context revealed features of as well liturgical like the theatre actions. The combining of the rhythms of liturgical life with the community-building scenic activities associated with the different periodic forms of music architectonics. Librettos of Silesian meditationes preserved in Wrocław University Library juxtaposed to some compositions connected to this practice confirms the key role of music there. For the participants of meditationes the music was a medium of rhetorically amplified affect, coded (as affectus musicus) and received on the level of the receiver's psyche. Its purpose was to interiorize the message and to retain it in the man's volitive sphere.

59 BREUER, Dieter. Der Zodiacus Laetofatalis des Bartholomäus Christelius SJ und die jesuitische Meditationsliteratur. In Bohemia Jesuitica 1556-2006. Eds. CEMUS, Petronila, Prague: Karolinum, 2010, p. 793-803. 


\section{Key words}

Jesuits, music, meditations, confraternities, passion music

\section{Bibliography}

BREUER, Dieter. Der Zodiacus Laetofatalis des Bartholomäus Christelius SJ und die jesuitische Meditationsliteratur. In Bohemia Jesuitica 1556-2006. Eds. CEMUS, Petronila. Praha: Karolinum, 2010, p. 793-803.

ERLACH, Thomas. Unterhaltung und Belehrung im Jesuitentheater um 1700: Untersuchungen zu Musik, Text und Kontext ausgewählter Stücke. Essen: Die Blaue Eule, 2006.

HOFFMANN, Hermann. Die Jesuiten in Oppeln. Die Tätigkeit der Jesuiten in d. Fürstentümern Oppeln u. Ratibor, den Standesherrschaften Beuthen und Pleß, in Oberglogau und Ziemientzitz, in Oppeln Tarnowitz und Piekar, in den Volksmissionen und den neuen Niederlassungen (Zur schlesischen Kirchengeschichte, 8). Breslau: Frankes Verlag, Otto Borgemeyer 1934.

JEŻ, Tomasz. Kultura muzyczna jezuitów na Śląsku i ziemi kłodzkiej (1581-1776). Warszawa, Wydawnictwo Naukowe Sub Lupa, 2013.

KAPSA, Václav. Jesuiten komponieren. Bemerkungen zu den erhaltenen Kompositionen der böhmischen Jesuiten. In. Aurora Musas nutrit - Die Jesuiten und die Kultur Mitteleuropas im 16.18. Jahrhundert. Acta conventus, Bratislavae 26.-29. Septembris 2007. Eds. KAČIC, Ladislav, ZAVARSKÝ, Svorad. Bratislava: Slavistický ústav Jána Stanislava SAV, Teologická fakulta Trnavskej univerzity, 2008, p. 193-208, here p. 196-198.

LANG, Franz. Theatrum affectuum humanorum, sive considerationes morales ad scenam accomodatae... München: Mathias Riedl 1717.

LANG, Franz. Theatrum doloris et amoris sive considerationes mysteriarum Chrtisti patientis... München: Mathias Riedl 1717.

LANG, Franz. Theatrum solitudinis asceticae, sive doctrinae morales per considerationes melodicas ad normam S. Exercitiorum S. P. Ignatii compositae... München: Mathias Riedl 1717.

MAGNIEZ, Anne-Claire. Des Exercices spirituels théâtralisés et musicaux. L'exemple du Theatrum Solitudinis Asceticae de Franciscus Lang SJ (1717). In Aurora Musas nutrit - Die Jesuiten und die Kultur Mitteleuropas im 16.-18. Jahrhundert. Acta conventus, Bratislavae 26.-29. Septembris 2007. Eds. KAČIC, Ladislav, ZAVARSKÝ, Svorad. Bratislava: Slavistický ústav Jána Stanislava SAV, Teologická fakulta Trnavskej univerzity, 2008, p. 135-144.

MAŇAS, Vladimír. Hudební aktivity náboženských korporací na Moravě v raném novověku. Disertační práce, Ústav hudební vědy Filozofické fakulty Masarykovy univerzity, Brno 2008.

MASEN, Jakob. Palaestra eloquentiae ligatae dramatica ... Köln: Johannes Busaeus, 1657.

ORLITA, Zdeněk. Postní a velikonoční období v praxi olomouckých jezuitských sodalit v druhé polovině 17. století. Časopis Matice moravské, 2006, vol. 125, no. 1, p. 53-76.

SAMMER, Marianne. Die Fastenmeditation. Gattungstheoretische Grundlegung und kulturgeschichtlicher Kontext. München: tuduv 1996 (Kulturgeschichtliche Forschungen 22. Ed. MOSER, Dietz-Rüdiger).

SCHMIDL, Johann. Historiae Societatis Jesu provinciae Bohemiae... Praha, 1754.

SCHNITZLER, Henry. The Jesuit Contribution to the Theatre. Educational Theatre Journal, 1952, vol. 4, no. 4. p. 283-292.

STECZEK, Bogusław, KOŁACZ, Jakub (eds). Konstytucje Towarzystwa Jezusowego wraz z przypisami Kongregacji Generalnej XXIV oraz Normy uzupetniajace zatwierdzone przez tę sama Kongregację. Kraków: Wydawnictwo WAM, Warszawa: Polskie Prowincje Towarzystwa Jezusowego, 2006.

TROLDA, Emilián. Jesuité a hudba. Cyril, 1940, vol. LXVI, nos. 5-6, p. 53-57, 1940, vol. LXVI, nos. 7-8, p. 73-78; 1941, vol. LXVII, nos. 1-2, p. 2-10, 1941, vol. LXVII, nos. 3-4, p. 42-46, 1941, vol. LXVII, nos. 5-6, p. 53-63, 1941, vol. LXVII, nos. 7-10, p. 106-108. 
VALENTIN, Jean Marie. Les jésuites et le théâtre (1554-1680). Contribution à l'histoire culturelle du monde catholique dans le Saint-Empire romain germanique. Ed. BEHAR, Pierre, Paris: Desjonquères, 2001. 
